\title{
COSMOPOLÍTICA CONSTITUINTE DA COMPLEXIDADE NA BOLÍVIA: A CONSTITUIÇÃO "6 ABERTA" E O SURGIMENTO DO ESTADO
} PLURINACIONAL

\author{
Salvador Schavelzon - Universidade Federal de São Paulo (UNIFESP)
}

O Estado assume e promove como princípios ético-morais da sociedade plural: ama qhilla, llulla ama, ama suwa (não sejas preguiçoso, não mintas, não sejas ladrão), suma qamaña (viver bem), ñandereko (vida harmoniosa), teko kavi (vida boa), ivi maraei (terra sem mal) e qhapaj ñan (caminho ou vida nobre).

Constituição Política do Estado da Bolívia de 2009 (Art. 8.1)

\section{LEITURAS DIVERGENTES DO PROCESSO CONSTITUINTE BOLIVIANO}

É possível pensar uma crítica ao Estado a partir de dentro do Estado? É possível superar o modelo republicano liberal a partir de uma república moldada pelo liberalismo? É possível pensar em um Estado que não neutralize a diferença e a pluralidade? Isso foi o que tentaram os indígenas e camponeses, pela primeira vez no governo da Bolívia com a eleição de Evo Morales, em dezembro de 2005. Os constituintes do Movimento ao Socialismo (MAS) tentaram transformar essa crítica em reformas políticas moldadas no projeto do Estado Plurinacional Comunitário. Esta proposta avançou pelo caminho do pluralismo jurídico e do reconhecimento da diferença, mas, ao mesmo tempo, resultou em uma forma política complexa que buscou se conjugar com um interesse pelo "social", pela “inclusão" e pela "soberania nacional". Tentou combinar a luta pela diferença com a luta contra a desigualdade.

Em oposição à proposta de uma nova ordem constitucional, escutavam-se vozes que falavam de ameaça à legalidade e às instituições, ou de "engano" e "incoerência", buscando impugnar o que era contraditório, sem sentido, violento, antirrepublicano ou "populista". Neste artigo, interessa-nos fazer um mapa destas discussões que acompanharam a elaboração de uma Constituição que foi aprovada pela população e promulgada em 2009. Nosso objetivo imediato é registrar as reações à mera sugestão de elementos alternativos ao constitucionalismo moderno e liberal.

A Assembleia Constituinte foi convocada no contexto de chegada do "primeiro partido de massas liderado por camponeses e indígenas na história da Bolívia" ao governo (KLEIN, 2011). O MAS foi formado por sindicatos do campo em 1995, e depois de dez anos chegou à presidência dando lugar à chamada "Revolução Democrática Cultural'. Em janeiro de 2006 teve início o mandato de Evo Morales e, em março, foi aprovada a lei de convocação da Assembleia Constituinte. Em julho, os constituintes foram eleitos com 54\% para MAS, resultado que repetiu o alcançado na eleição presidencial e significou a vitória de uma elevada percentagem de representantes camponeses e ativistas sociais que, até então, se encontravam excluídos do poder político tradicional. Era notável como a folha 
de coca, as "polleras" (grandes saias das camponesas andinas), os chapéus e os ponchos faziam agora parte do poder estatal, como nunca antes.

Simultaneamente à eleição dos Constituintes, em um referendum nacional, as regiões do oriente e sul do país se manifestaram a favor das "autonomias dos departamentos". Evo Morales e o MAS recomendaram a rejeição desta proposta, e os resultados polarizaram o cenário político sobre o tema, com metade do país contra e outra a favor. Fortes mobilizações conseguiram que o novo governo aceitasse incorporar as autonomias dos nove departamentos à nova Constituição. No entanto, essa medida foi aceita ao lado da proposta de autonomias indígenas e no marco da plurinacionalidade. Soberania econômica, mais direitos, participação e orientação social também faziam parte da agenda constitucional. E a reivindicação de Sucre pelo retorno dos poderes executivos e legislativos (perdidos em 1899) se impôs, junto à autonomia departamental, como os principais obstáculos para o MAS na Assembleia .

Uma vez iniciado o processo constituinte, seu ritmo mostrou-se imprevisível e em constante transformação. Ninguém imaginava a forma que a constituição seria finalmente aprovada. Ninguém poderia, também, prever seu conteúdo e as reformas implementadas em relação à Constituição anterior. Ao longo de sua trajetória, a Assembleia Constituinte teve que ser ampliada porque não conseguiu elaborar um novo texto no prazo estabelecido. A aprovação final do texto na Assembleia Constituinte, em dezembro de 2007, foi realizada em sessões acompanhadas de protestos e manifestações de apoio, com a morte de manifestantes nas ruas, regiões sublevadas, evacuação de constituintes pelas montanhas e transferências sucessivas da sede da Assembleia para um quartel e uma universidade em departamentos diferentes. O texto que se pensou definitivamente aprovado pela Assembleia foi reaberto em outubro de 2008, por parlamentares não autorizados legal ou previamente para fazê-lo. Eles modificaram 120 artigos (dos 411) da Constituição, que foi finalmente aprovada em um referendum com a ratificação de $62,4 \%$ dos eleitores.

Este cenário contrariou àqueles que esperavam um caminho institucional sem sobressaltos ou reformas institucionais que não pusessem em questão o marco institucional vigente. A improvisação e desordem parecem previsíveis e naturais em um processo que enunciava importantes questionamentos sobre as formas republicanas. De modo insistente, no entanto, atores políticos opositores ao MAS construíram suas posições contra esse "caos", “desordem”, ou “improvisação", que eles associavam ao ambiente "popular” na Assembleia, com a nostalgia de uma ordem anterior conturbada por aquilo que viam como incompreensível barbárie. As formas políticas, econômicas ou jurídicas da comunidade eram, do ponto de vista dessas posições, "subformas", válidas apenas para o âmbito local e aspectos folclóricos que não interpelam as formas tradicionais. Para eles, a existência da comunidade e seu sistema político ligado às colheitas, relações de parentesco e festividades, não era algo que tinha de ser levado em conta no momento de elaboração de uma Constituição. O debate político na Bolívia, assim, se manifestou, em primeiro lugar, como impossibilidade de compreensão entre diferenças epistêmicas radicais. Considerando as forças políticas que se reuniam na Assembleia, vemos uma forte controvérsia entre formas diferentes de entender o que estava sendo discutido e entre formas diferentes de discordar(WAGNER, 1975).

Para a oposição liberal, na Assembleia se encontravam a tradição pré-moderna do campo com a modernidade 
dos defensores letrados das leis e do progresso. Para o indianismo pluralista, tratava-se do antigo e atual embate entre a diferença indígena e a autoridade colonial excludente, apesar de sua forma republicana. No último caso, trata-se do olhar autóctone, inspirado pelo indianismo katarista com raízes na Qullasuyu pré-colonial; no outro, de um olhar que pretendia ser guiado por valores universais e modernos. Outro universalismo, o da esquerda socialista, em parte herdeira do antigo e forte movimento classista operário das minas bolivianas, apareceu articulado pelo MAS à visão local indígena, mas também combinada com ares nacionalistas que codificavam as diferenças como "povos" versus "antipovo" ou "oligarquia". Nas discussões da Assembleia, outro localismo proveniente das capitais das regiões do oriente e do sul (a Meia Lua ), com a demanda de autonomia departamental e descentralização administrativa, se articulou politicamente com o universalismo liberal de oposição ao governo indígena de inclinação social.

Mas esse esquema só é válido se considerarmos ainda posições intermediárias: o indígena, que da comunidade apoiava a construção de um Estado forte, e o liberal, que se abria à tarefa de incorporar formas indígenas porque entendia a violência estatal contra esses povos. No entanto, essa é a dinâmica política acessível apenas se olharmos de perto, como o método etnográfico possibilita. Sem uma linha ideológica uniforme e superpondo reivindicações com negociações, visões políticas contraditórias com necessidades do governo, a Assembleia Constituinte resultou em um texto no qual podem coexistir mundos políticos e imaginários sociais em princípio divergentes. Embora seja provável que qualquer texto escrito a muitas mãos consista, de alguma modo, em uma multiplicidade irredutível, a nova Constituição faz isso de uma maneira particular ao manter em sua complexidade uma resistência impossível de ser reduzida por qualquer ficção clássica do constitucionalismo liberal. A Constituição elaborada pelo MAS em negociação constante com outros atores seguiu o caminho oposto ao da primeira Constituição boliviana, enviada de Lima por Simon Bolívar em 1825 e adotada como texto fechado, que tentou impor uma linha liberal napoleônica aceita sem discussões ou revisão local na nascente República, com a exclusão dos indígenas e mulheres (cf. BARRAGÁN, 2006).

Ao tentar dar conta das dinâmicas das forças políticas, no contexto em que a institucionalidade e legalidade do direito estatal não podem ser analisadas sem considerar a exterioridade daqueles que pela primeira vez ocupavam o governo e emitiam uma voz constituinte, abordamos o processo constituinte com um olhar aberto ao caos eà diferença. Trata-se, aqui, de superar o reducionismo das análises que explicam o curso imprevisível da Assembleia evocando "contradição", "violência", "desordem" e "ilegalidade". Como inverso ao método etnográfico, estes eram juízos de valor emitidos a distância a respeito das cosmopolítica (STENGERS, 2011) indígenas e da articulação de seus diferentes mundos, que ensaiavam uma nova tradução da linguagem do Estado.

No caminho para compreender as complexidades da nova Constituição e do seu processo de elaboração e aprovação, vemos lado a lado as leituras sobre o processo constituinte a partir das ciências sociais e análises de atores políticos e jornalistas. Nelas, as caracterizações políticas e epistemológicas se encontram. Neste espaço, encontramos também BrunoLatour(1994) que, comametáfora da “constituiçãomoderna”, mostra a crise de umpensamento surgido no século XVI. Este pensamento se fechou aos híbridos e não-humanos em virtude da separação ("purificação") dos campos transcendentes natureza/sociedade e, assim, ocultou a proliferação de vozes não modernas que experiências 
comoas bolivianas colocamhoje sobreamesa.APachamama,oViverBem, umgoverno que continuaaser"Movimento Social" desafiavam os limites existentes até então, considerados inadequados do ponto de vista do Estado, unindo o que na ordem moderna devia permanecer separado: natureza e cultura, Estado e Sociedade, etnicidade e cidadania, participação e representação. Como Latour com a proposta do Parlamento das Coisas (LATOUR, 1994; STENGERS, 2011), na Bolívia, tratava-se de escutar, acompanhar e constitucionalizar modelos coletivos e híbridos de naturezacultura do pensamento indígena, para o qual a agência não é exclusivamente humana (DE LA CADENA, 2010) e a reciprocidade prevalece sobre acumulação. As discussões da Assembleia Constituinte também podem ser atribuídas ao que Corsin Jiménez (2013) descreve como Neobarroco, com os dispositivos de reversibilidade e estrabismo que se distanciam da mentalidade de governo típico da racionalidade moderna.

A proposta dos camponeses e indígenas no governo e na Assembleia Constituinte procurou ir além do modelo liberal e das oposições básicas de um sistema político fechado às maiorias, que insistia na oposição indígena/mestiço, individual/coletivo, racional/irracional, cultura universal/cultura ancestral; propriedade/reciprocidade. Na constituinte, o MAS assumiu a proposta de criação de um Estado Plurinacional Comunitário como articulação conceitual que significava distintos projetos políticos e que não era definida de forma clara e precisa, mas ainda assim - ou justamente por isso - foi interpretada como ameaça ou esperança de mudança para muitos que se mobilizaram no país a favor ou contra tal proposta. Seria uma confederação de nações? Ou simplesmente a inclusão dos excluídos? Seria um multiculturalismo que não sairia do papel? Ou seria algo novo? Alguns chamavam atenção para a origem comunista e soviética do conceito de plurinacionalidade. Para outros, o termo tinha origem no movimento indígena equatoriano; ou, então, seguia o caminho do liberalismo multicultural implementado na Bolívia nos anos 1990. O certo é que todas as origens e interpretações reverberaram em um formato constitucional que deixaram muitos espaços sem regulamentação.

Para explicar a dinâmica política em questão, vamos nos referir a um processo político e um texto jurídico denso e heterogêneo que definimos como Constituição "aberta" e "combinatória", que surgiu das tensões decorrentes entre tendências e visões políticas distintas. A fim de dar conta do seu conteúdo e do processo que a concebeu, adotamos uma epistemologia da complexidade sobre a qual escreveram Morin (1999) ou Deleuze e Guattari (2000), que nos ensinaram a ler um mundo de futuros em vez de dicotomias polarizantes e movimento em lugar de hierarquia. Para dar conta de um contexto etnográfico como o da discussão de uma nova forma de Estado, com a proposta do Estado Plurinacional Comunitário, cabe destacar o esforço de Law e Mol (2002) para entender práticas de conhecimento das coisas que se relacionam sem somar-se, ou eventos que não ocorrem em processos de tempo linear e fenômenos que compartilham um espaço, mas não podem ser mapeados em coordenadas tridimensionais. Esses autores chamam a atenção para simplificações e as formas modernas de ordenar, como também sobre a necessidade de escapar do dualismo "ordem" e "caos"(p.22).

Aanálise seria empobrecida se apresentarmos a discussão em termos de uma simples oposição entre hierarquia/ ordem/instituição/homogeneidade, de um lado, e de abertura/complexidade/combinação/pluralidade, de outro. 
Também não é útil opor um momento de luta, criação, movimento e crescimento, a um outro posterior, onde apenas se tratou de corte, instituição e enquadramento. De fato, nas discussões da Assembleia Constituinte a multiplicidade indígena buscou passar por um modelo hierárquico de organização, o Estado boliviano, e tentou moldar formas de governo nas quais o movimento estivesse contido. Uma situação que Deleuze e Guattari descrevem como "linhas de fuga e movimentos moleculares que voltam a passar pelas organizações molares" (2000, p.366). Apesar de evitar binarismos para entender uma proposta híbrida e impalpável, a minha posição no mapeamento de discussões não é a equidistância. Mas sim, encontro uma cumplicidade entre uma epistemologia aberta ao complexo e a proposta que saiu do espaço político do Pacto de Unidade, formado em 2004 entre as organizações camponesas e indígenas e se constituiu no espaço de diálogo que inspirou grande parte da proposta de plurinacionalidade.

Trata-se, aqui, de reconhecer a capacidade do pensamento e a autonomia cosmopolítica dos "camponeses indígenas" da Bolívia para transitar sem dificuldade as ambiguidades, coexistências, fluidez. As ontologias relacionais indígenas e, também, o contexto de uma sociedade colonial prepararam o caminho para isso.

\section{CONSTITUIÇÃO ILEGAL, INCONSISTENTE, FICTÍCIA, VIOLENTA E NÃO-RACIONAL}

Para começar, considerarei a perspectiva de oposição ao MAS na Assembleia proveniente do liberalismo local crítico à plurinacionalidade, a partir de algumas fontes secundárias de protagonistas do processo constitucional. No mesmo sentido de Dipesh Chacrabarty dos estudos subalternos da Índia (2007), a socióloga boliviana Silvia Rivera Cusicanqui (2006), assim como outros expoentes do indianismo, sugeriram tratar as formas europeias que acompanharam a colonização como formas não universais, mas locais que surgiram na Itália, França, etc. Na mesma linha de pensamento, os argumentos liberais da Assembleia Constituinte nos remetem a autores que estudaram as particularidades de cada liberalismo em sua singularidade local de diferentes processos de formação do Estado na América (cf. COLBURN \& CRUZ, 2007; JOSEPH \& NUGENT, 2002; HALE, 1972). Nesta seção, será discutido o papel de tal tendência política nos debates do contexto constituinte.

Um constituinte opositor ao MAS naAssembleia, representante de Cochabamba, Gamal Serham, fezuma lista de irregularidades do MAS na Assembleia em seu livro La Historia no Oficial de la Asamblea Constituyente (2008). Neste livro considera a aprovação da Constituição - que ainda não era a definitiva - "ilegal” (p. 22), associa a ideia do Estado Plurinacional a uma "lógica ETArrista [sic], que a única coisa que busca é dividir país" (p.27), e vê a ideia de "Participação e Controle Social” como "emulando aos Soviets da antiga URSS" (p. 28). Ele se uniu aos opositores de Sucre que reivindicavam o retorno dos poderes executivo e legislativo à cidade, e que, por representarem a sede do poder judiciário, ameaçaram várias vezes intervir na Assembleia através de meios legais e mobilizações. Entre a lei e as medidas de força, também se encontrava a principal força de oposição formada pelos constituintes da Meia Luna, que em sua busca de autonomia adotaram a estratégia de impor estatutos autonômicos aprovados pela maioria da população dos departamentos, mas elaborados em reuniões autoconvocadas, sem respeitar os procedimentos ou as normas pré-estabelecidas, embora fossem apresentados como defesas liberais contra a ilegalidade, o populismo e o 
totalitarismo indígena, que do ponto de vista do centralismo deterioravam o Estado de Direito.

Uma das vozes da Meia Lua naAssembleia foi a de Juan Carlos Urenda, advogado que coordenou a elaboração do projeto autonômico e depois o Estatuto de Santa Cruz. Em um de seus livros (2009) apresenta uma análise da Constituição e, como outros, avança no caminho da denúncia de "inconsistências". Urenda propõe para explicar a Constituição de 2009, a imagem de "O Estado Catoblepas", retomando a figura lendária de um animal monstruoso usado anteriormente por Mario Vargas Llosa, guia político para boa parte do liberalismo latino-americano. A Nova Constituição, segundo Urenda, contém a semente de sua própria inviabilidade, a partir de cinco contradições descritas pelo autor da seguinte forma: 1) o princípio da igualdade violado pelo racismo expresso que permeia seu texto, 2) o sistema democrático corroído pelo controle social fascista, 3) o regime de autonomias departamentais anulado por um sistema de competência torpementemente centralizado, 4) o desenvolvimento econômico limitado pela tendência ao estatismo comunitarista e um regime de investimentos sobre recursos naturais absolutamente desalentadore 5) a justiça como uma função essencial do Estado, que tem na justiça comunitária o germe de um mar de injustiças (2009, p.7). As ideias de "contradição", "desordem", "incoerência", "violência” e “ilegalidade” dominam suas análises.

Entre as leituras que priorizam a contradição em vez da possibilidade e combinação, encontramos a do jornalista pacenho Fernando Molina. Este analista assume uma posição progressista liberal e acredita que as inovações plurinacionais do texto são uma “ficção legal” (2009, p.3). Para este autor, a Nova Constituição postulava a superação da república, sem realizá-la e, sobretudo, levava ao extremo a concepção da Bolívia como uma sociedade não homogênea e diversa, "não nacional e fragmentária", noção introduzida desde as reformas constitucionais de 1995. O texto constitucional retoma a matriz da economia estatizada com influência nacionalista, socialista e antiliberal, que é, segundo ele, a principal "ideologia boliviana” da atualidade. Molina descreve as fontes da nova Constituição da seguinte forma:

“(...) 70\% ou mais da Constituição é baseada no republicanismo latino (soberania popular, separação de poderes), o liberalismo inglês (limitação do Estado através da definição dos direitos civis e pessoal) e o liberalismo francês (direitos políticos, princípio de não discriminação). A autodeterminação dos povos indígenas foi tomada do acervo da esquerda europeia. A descolonização é um conceito "pós-colonial”, isto é, desenvolvido em escolas do primeiro mundo, etc." (MOLINA, 2009, p.41).

Mas a mistura e combinação de diferentes vertentes (particularmente, o indianismo e o nacionalismo antiliberal) deram um "caráter híbrido e mesmo contraditório da filosofia dessa Constituição, que por um lado aponta para a centralização e a acumulação do poder e, por outro, oferece garantias políticas e oportunidades de governo a inúmeras entidades subnacionais, em particular os povos indígenas". Sobre essa situação, o autor prevê que as duas tendências são incompatíveis e, sob uma perspectiva fechada à complexidade, sugere que um dos dois aspectos deverá necessariamente fracassar (2009, p.6). Para este autor, a autonomia não pode ir junto com o controle dos recursos naturais e a liberdade não combina com formas comunitárias. Em suas críticas ao texto constitucional, Molina assinala que a propriedade coletiva e a propriedade comunitária limitam a liberdade econômica e a propriedade privada. $\mathrm{O}$ 
autor reconhece que a exploração privada de recursos não renováveis é aceita, mas ressalta que a Constituição de 2009 “evita falar, e só o faz com eufemismos”. Ele critica, também, a propriedade estatal e a sentença constitucional de que "a utilização da propriedade não deve ser prejudicial ao interesse público", considerando-as como duas maneiras que atacam a propriedade privada (2009, p.13).

Em outro artigo, Molina (2011) apresenta uma leitura negativa sobre a combinação de elementos de origem diversa e um processo complexo que não mostra um sentido homogêneo, único e sem tensões, que

“na panela de pressão dos acontecimentos históricos e dos ritmos de poder, convertem-se em uma espécie de 'puré' no qual se misturam, indistinguíveis, ideais com conveniências; fatos com mentiras; giros à direita, à esquerda e ao centro; o estatismo com grandes lucros privados; indianismo naturalista com a degradação ambiental; o progressismo com o machismo, homofobia, etc."

$\mathrm{Na}$ linha da denúncia de uma espécie de fraude ou engano, comum às críticas ao indianismo aimará tanto quanto ao nacionalismo de esquerda e, neste caso, a partir do liberalismo, Molina prossegue: "O que fica, então, da 'novidade plurinacional'? Apenas ficções jurídicas, tais como a atribuição aos povos do estatuto de 'nações', que não são traduzidos em qualquer prerrogativa do Estado" (2011, s/d).

O que chama a atenção nas críticas ao projeto da Constituição, e mostra o seu caráter multiforme e ambíguo no qual insistimos, é que ao mesmo tempo que é considerado algo ameaçador e supérfluo, meramente retórico, com efeitos apenas fictícios, é também uma ameaça que vai contra os princípios básicos e da legalidade estatal. Molina acredita que o indianismo é sua ideologia, mas que a mesma não foi introduzida em seus artigos. Sua leitura geral éa de ficção, engano, simbolismo sem materialidade nem consequências reais. Na continuação, examinaremos uma leitura que busca equilibrar a análise novamente para o lado da ameaça real contra o Estado de Direito e a liberdade.

Outro exemplo de posições "purificadoras" (LATOUR,1994), "institucionalistas" e modernas na Assembleia Constituinte foram as defendidos por Jorge Lazarte, cientista político e analista, eleito em La Paz por um dos partidos de oposição ao governo (a Unidade Nacional - UN, do qual em seguida se afasta), sobre quem trataremos adiante mais detalhadamente por ser, talvez, o representante desse perspectiva que mais escreveu sobre a Assembleia. Lazarte foi responsável por apresentar o relatório da oposição na Comissão Visão do País, embora não tivesse autorização para votar. Nessa ocasião, disse que o MAS “estava brincando de aprendiz de feiticeiro”, por combinar o Plurinacional com o Unitário, para ele uma “contradição explosiva” (SCHAVELZON, 2010). Registramos em nosso caderno de campo que Lazarte afirmou que o Estado Plurinacional era uma "experiência", pois em nenhum país do mundo existia algo assim, e que com isso se "despreza o Estado de Direito, parte inerente do Estado moderno para pôr limites ao poder". Lazarte afirmou que pela unidade do país, o Estado não podia se basear na diferença étnica assim como fizeram Franco e Hitler. Na fundamentação do projeto do relatório por minoria também criticou a ideia de "nações indígenas" e disse que “não há nenhuma raça aymara ou quéchua, porque eles estão misturados, uma vez que o 'sombrero' e a 'pollera' vêm dos espanhóis" (SCHAVELZON, 2010). 
Jorge Lazarte expressou a sua visão no capítulo de um livro Lo que unos quieren recordar, otros no pueden olvidar (ZUAZO QUIROGA; MARTIN, 2011), com o qual trabalhamos a seguir. A descrição de Lazarte (2011) sobre as negociações nos primeiros meses da Assembleia revela o caos e a complexidade do cenário, mas a sua análise impõe a simplificação. Para Lazarte, apesar do acordo e aprovação final, a Assembleia Constituinte fracassou e não foi possível realizar o pacto. Ele considerou que a Assembleia foi apenas um campo de "confrontação" e "enfrentamento", onde "a palavra foi substituída pela violência" (2011, p.323). Esta avaliação é entendida a partir de uma ideia abstrata de Assembleia Constituinte e processos políticos inspirados por Jon Elster e de sua definição de procedimentos com base em acordos de argumentos racionais, na "força do melhor argumento, com critérios de validade e credibilidade e causa e efeito observável" (LAZARTE 2011, p.352). Isso é para Lazarte, o marco deliberativo e democrático das decisões que no processo boliviano fracassaram, dando origem à negociação, definida por Lazarte também a partir de Elster, como "ameaças, promessas e negociações".

Esta concepção fecha os olhos para a importância dos elementos externos da institucionalidade formal, para a desordem e conflito que coexistem com a lei, mesmo depois desta ser promulgada. O modelo de Lazarte parece ser o de poucos iguais debatendo com muitos diferentes fora da discussão. Dessa forma, o externo, o lado de fora não intervém em uma explicação que novamente se apoia na contradição e não na combinação. Em seu artigo, Lazarte explica o que vê como fracasso aludindo a diversos fatores avaliados negativamente: pressões "extra legais", "intervenção de atores externos"; "candidatos a constituintes improvisados e com argumentos ideológicos"; candidatos "mais representativos que competentes"; "opinião pública pouco interessada em controvérsias tão altas, tão novas ou incompreensíveis para ela"; "insistência no caráter plenipotenciário da Assembleia Constituinte", "falta de debate", entre outros (p.335-337, 350,381 e passim).

A perspectiva de Lazarte opõe racionalidade/irracionalidade, posicionando-se do lado do saber, da legalidade e da razão, diante dos constituintes do MAS, considerados com menos recursos de conhecimento para participar do que ele considera um "debate racional". Do ponto de vista político, aliás, não é difícil entender o vínculo desse olhar com o constitucionalismo liberal republicanoestabelecidona Bolívia desde 1826e, também, comaideia de que os camponeses constituintes do MAS não estavam capacitados a participar de uma Assembleia Constituinte. Esta era a posição do campo político onde Lazarte se encontrava, de frente para a Bolívia Indígena, cuja voz tinha ganhado protagonismo estatal pela primeira vez. A divisão racionalidade/irracionalidade fica evidente quando Lazarte escreve que "em vez de argumentos racionais, havia elevação do tom de voz, repetições sobre o neocolonialismo, o neoliberalismo, os 500 anos" (p.397) e se refere ao "que pode ser chamado de argumento", uma vez mais insultando a proposta do MAS, que não é vista como argumento, mas sim como "uma mistura sui generis de crítica filosófica pós-moderna da modernidade com reivindicacionistas de formas sociais tradicionais e arcaico-ancestrais" (p.386). Cabe esclarecer que a partir de uma mentalidade "purificadora" essa descrição é desqualificadora. De modo depreciativo, também escreve que a maioria indígena-originaria defendia uma Assembleia "originária" - em vez de "derivada" - por acreditar que "originária" se referia a eles (nota 48, p.364). O desprezo pelos opositores políticos e a distância do processo que estava acontecendo diante dele também aparecem quando afirma que o plurilinguismo era uma reivindicação não 
compreendida (nota 57, p.7). .

Outro elemento apontando por Jorge Lazarte para concluir com o "fracasso" do processo constituinte se refere a que os constituintes eram portadores de mandatos de organizações sociais, que consultavam suas bases, antes de serem portadores de mandato individual: "mais mandantes que representantes no sentido moderno democrático" (p.347). A intervenção de organizações sociais ou constituintes provenientes de organizações camponesas e indígenas que atuavam em conjunto e só depois de consultar as bases representava o orgulho do MAS, que avaliava as trajetórias de seus constituintes com base nas lutas dos últimos anos. A oposição da qual este constituinte fazia parte, no entanto, via a falta de individualidade no mandato como uma anomalia. Lazarte critica que o chamado "participacionismo" está acima da forma institucional e da Assembleia Constituinte e associa-o à “democracia comunitária”, que a Constituição reconhece, mas em suas palavras, "não permite discordância como uma 'democracia importada"” (p.250) e onde há “obrigação consenso" (p.390).

Sobre a ideia do plurinacional, que considera como “expressão de valor simbólico-normativo que poderia cobrir tudo e abrir um novo mundo" (p.385), Lazarte advertiu sobre uma “proposta plurinacional não apenas simbólica ou de reconhecimento de direitos, mas a matriz para reconfigurar todo o sistema institucional e eleitoral do país levando ao poder total" (p.391). Esta definição reconhece a força de uma proposta que às vezes é limitada pela análise apresentada como mera retórica sem a capacidade de mudar a realidade. Como extremos que se encontram, sua visão se aproxima do indianismo aimará, ainda que se refira a "duas Bolívias", uma branca e outra indígena, sem nada no meio. Ambas simplificações são fortes como imagem política, mas não permitem o acesso à complexidade, às combinações e à ambiguidade que estava sobre a mesa da redação nesta Assembleia.

Em sua crítica à substituição do nome República por Estado Plurinacional na denominação do país, em 18 de março de 2009 após a aprovação da Constituição, Lazarte considerou que o governo tinha apagado por decreto um dos poucos símbolos políticos universais, e que "Nem mesmo os fundamentalistas xiitas do Irã foram tão longe em sua revolução e optaram pela República Islâmica. Nem os bolcheviques se atreveram a este tipo de niilismo político", escreveu. Lazarte refere-se a "queixas coletivas" e "fundamentalismo arcaico que condena o passado recente, em nome de um passado mítico". O Estado Plurinacional seria “uma concepção diametralmente oposta à democracia, que substitui a república dos cidadãos pelo Estado Plurinacional da etnia”(LAPRENSA, 2009, s/d).

Seja a partir do liberalismo progressivo do jornalista pacenho Molina, ou dos sectores de empresários e autonomistas de Santa Cruz representados por Urenda, ou na escrita do cientista político e constituinte liberal de oposição ao MAS, Jorge Lazarte, vemos denúncias e incompreensão da proposta indígena e camponesa. A proposta do MAS, a sua ação política e a própria direção da Assembleia, era explicada como pós-moderna e pré-moderna, como inconsistente e contraditória como um modelo político, mas, ao mesmo tempo, também eficaz na destruição de instituições. Era considerada "populista" a partir de um republicanismo liberal que longe de representar posições progressistas, como em relação ao antigo regime na Europa, na Bolívia representava a posição conservadora fechada ao reconhecimento da diferença indígena. 
Contra a proposta do Estado Plurinacional, a oposição alegou defender a Nação (que estaria ameaçada pelo reconhecimento territorial de etnias), defender a República (em perigo com o reconhecimento de formas comunitárias, direitos coletivos ancestrais e "participacionismo corporativo") e defender "Estado de Direito" (contra o qual se visualizava um "regime populista autoritário"). A temática indígena, para estes adversários, devia ser reduzida a história e ao folclore, enquanto o presente das comunidades camponesas era associado à pobreza e à necessidade de acesso ao mercado, com todos os gestos paternalistas que teoricamente não estariam relacionados ao liberalismo clássico, mas que na Bolívia o caracterizavam. A crítica da proposta do MAS e do Pacto de Unidade surgiu dos defensores locais do liberalismo e republicanismo de inspiração universal, mas de expressão local como ideologia da elite europeizada governante até 2006. Na Assembleia, estas eram vozes provenientes de constituintes identificados como "classe média", "profissional", "urbano" e de identidade "mestiça", mas que também, falavam com um discurso regionalista que exigia descentralização e maior controle sobre os recursos naturais e a terra.

Na continuação, examinaremos a proposta indígena contra a qual as vozes citadas acima reagiam. Antes do conteúdo da proposta aprovada na Constituição, estamos interessados na forma pela qual esta proposta acontecia no interior do Estado. Mas a forma e o conteúdo devem ser estudados em continuidade, como parte de uma proposta que reflete uma cosmopolítica alternativa, um pensamento nômade que escapa à cristalização na escritura estatal.

\section{A ETNOGRAFIA DA INDEFINIBILIDADE DOS CONCEITOS SELVAGENS}

No trabalho de campo antropológico naAssembleia Constituinte, vimos que muitas vezes a posição dos setores mais preocupados com o Estado de Direito - dentro e fora do MAS - não era uma simples contestação das propostas indígenas. Apresentava-se mais como exigência de definição e explicação do que consistiriam tais inovações, quais seriam seus limites e atribuições e como se articulariam com a lei estadual existente. No momento em que seriam transformadas em artigos constitucionais, as propostas não eram rejeitadas de imediato, mas eram limitadas na forma de definição e desenvolvimento de suas características. Assim, a incorporação do autogoverno indígena e do pluralismo trouxe problemas aos diversos constituintes que viam com preocupação deixar temas “abertos”.

Poralgum tempo, a incorporação das questões indígenas ao direito liberal e republicano estava longe de seruma novidade ou ameaça. O ponto era que a definição precisa destacava elementos incompatíveis das instituições indígenas com um sistema estatal não aberto à diferença. Nas reuniões da redação se discutia a forma de constitucionalizar reivindicações que muitas vezes não estavam em conformidade com as instituições estaduais vigentes. A busca pelo reconhecimento da justiça oral, as decisões por consenso na assembleia comunitária, os métodos tradicionais de rotação de poder e reciprocidade de obrigações e deveres, perdiam consistência quando passavam a ser definidas com rigor. Por ter origens fora do Estado, as demandas indígenas vinculadas à sua autonomia e às formas outras de governo ou organização eram muitas vezes mais dificeis de serem incorporadas que as de inspiração social ou liberal, sendo as primeiras a cair na mesa de negociação. Os atritos relativos à inserção de formas externas ao Estado enfrentaram na Assembleia os sindicatos camponeses e as organizações indígenas, empenhados em recuperar formas ancestrais de 
organização para substituir o sindicato, que estava associado ao estado nacionalista da reforma agrária de 1953.

Foi neste momento, diante das exigências de definição, que o trabalho de constitucionalizar adquiriu para os povos indígenas e seus assessores um alto grau de sofisticação e sutileza estratégica. Redigir uma constituição passou a ser, muitas vezes, constitucionalizar silêncios sobre temas que era melhor não incluir ou que fossem incluídos de modo limitado ou fechado em relação ao seu possível futuro alcance. As discussões incidiram, especialmente, sobre a forma pela qual os elementos indígenas seriam introduzidos: se de acordo com o modelo multicultural já em vigor na Bolívia, tendência que agregou muitas propostas da oposição, ou se com o "plurinacional", conceito ainda não definido, mas que mesmo assim era ameaçador como possibilidade de um constitucionalismo diferente.

Com séculos de existência autônoma ou de resistência ao Estado, a comunidade exigia uma saída aberta. No entanto, quando ficava evidente que não era possível “ir mais longe", a resolução, então, se tornava indefinida, ambígua ou até mesmo contraditória. Além das imprecisões decorrentes dos conflitos políticos e cenários improvisados da redação, revisão e aprovação do texto, parte da abertura conceitual foi resultado de estratégias e habilidade para preservar o que dificilmente poderia ser traduzido para o código estatal. Silêncio e indefinição ganharam espaço diante de um sentido comum do direito estatal que exigiu, acima de tudo, mais definição e menos possibilidade de diferença não domesticada que fosse legalizada na estrutura constitucional. Era o medo ao amorfo, flexível ou não individualizável, além da luta concreta por interesses específicos, como os que se referem à possessão da terra.

Nas reuniões de redação do texto, um constituinte do Movimento Nacional Revolucionário(MNR), que votou pelo MAS na Comissão de Autonomia, declarou não ser possível que cada território tivesse normas diferentes e, para isso, propôs a inclusão na Constituição que as autonomias indígenas tivessem estatutos escritos com normas de acordo com a lei e controle do governo central. As normas devem ser genéricas, disse ele. O presidente da Comissão de Autonomias do MAS, enquanto elaborava com seus companheiros a proposta oficialista, declarou que não se opunha a um elevado número de territórios indígenas com autonomia, desde que estes estivessem claramente estabelecidos na Constituição. Desse modo, não poderia haver uma lista aberta. Não concordava, também, com o reconhecimento de milhares de hectares em territórios onde população é baixa. Ele considerava que sem definição, haveria caos e, então, solicitou censos, mapas, registros históricos como meio de acesso ao reconhecimento e para evitar a "imprecisão". Também temia que os quéchua e aimarás da cidade, sem nenhuma estrutura social ou organizacional indígena, obtivessem autodeterminação. Dessa forma, entendia que "se poderia ajudar mais aos índios". Ele estava preocupado com a acusação da oposição, que falava de "povos indígenas falsos" (SCHAVELZON, 2010).

Mas o Pacto de Unidade tinha a posição explícita de que nem tudo devia ser definido, e isso era defendido pelos seus assessores e constituintes na Assembleia. Predominava a ideia de processo gradual pelo qual muitos povos iriam consolidando seus territórios ancestrais em avanços institucionais internos progressivos, após a aprovação da nova Constituição. Sobre as formas de acesso à Autonomia Indígena, uma dos temas abertos e indefinidos no debate, algumas comunidades explicaram que se associariam para formar governos autônomos sem divisões, superando os velhos limites que lhes foram impostos. Outros povos indígenas, explicavam seus líderes, preferiam a estratégia de 
consolidar unidades menores, onde demograficamente fosse possível, ebuscar a unidade mais tarde. Enquanto nos anos anteriores alguns povos tinham conseguido a titulação de terras, outros estavam a caminho. Especialistas afirmavam que em virtude da dinâmica étnica não era apropriado definir um número de povos na Constituição, pois estavam em constante crescimento e diminuição. Algumas das preocupações dos "defensores do Estado de Direito" foram atendidas e, além de restringir a autonomia a limites municipais já existentes, ficou estabelecido que estes poderiam se associar, sem jamais exceder os limites departamentais. Também não seriam respeitados os mecanismos tradicionais de tomada de decisão e as mudanças iriam depender de referendos aprovados pelas instituições municipais.

O caso mais claro de abertura eram as grandes declarações, depois relativizadas em artigos dispersos. Houve avanços pluralistasnoprimeiro artigoquedeclarouaBolíviafundadanopluralismojurídico, político,cultural, econômico e linguístico, que se materializa com a formalização das 36 línguas indígenas e o castelhano em igualdade de hierarquia e com a obrigação de que os funcionários do Estado falem pelo menos uma delas, além de espanhol. No entanto, esta questão perdeu força com o acréscimo em outubro 2008, quando ficou estabelecido que a sua implementação seria "progressiva". A igualdade de hierarquia entre as formas estatais e indígenas se estende às formas econômicas, de governo, de justiça e territoriais. No entanto, em outros artigos também se afirma o contrário, ao conceder menos competências para as autonomias indígenas que as departamentais e o governo central, que manteve sua forma Unitária, ou quando a democracia representativa se sobrepõe à comunitária e o sistema educacional permanece centralizado.

A democracia comunitária, a economia do ayllu, a justiça indígena e suas formas institucionais próprias têm garantias constitucionais, mas não se definiu a integração das mesmas ao Estado. Indicaram, ainda, futuras leis, como a Lei de Deslinde Jurisdicional da justiça indígena originária e campesina e a Lei Marco de Autonomias. Da mesma forma, abriram-se as portas para levar adiante um modelo alternativo de desenvolvimento, inspirado no "Viver Bem" dos povos indígenas andinos e amazônicos. No entanto, estes aparecem enunciados como intenções constitucionais sem elementos reais que se contraponham ao modelo de desenvolvimento vigente, que é impulsionado por vários mandatos da mesma Constituição em favor da industrialização. Em resumo, o pluralismo é aceito e incorporado de forma indefinida, sem permitir que a oposição do MAS consiga excluí-lo, mas, também, não se avançando firmemente para garantir o seu desenvolvimento .

Nos debates das comissões que redigiam o texto constitucional, um dos técnicos constitucionalistas da oposição rejeitou, em uma das reuniões observadas, a clássica fórmula de "usos e costumes" e "formas próprias" dos indígenas. Era muito aberto, disse ele. Outros opositores previram uma guerra civil se a autonomia fosse autorizada em territórios indígenas sem uma definição de seu alcance. A imagem que se apresentava sobre tal reconhecimento era de uma disputa territorial do tipo feudal que comprometia a unidade da Bolívia. A oposição também alertava sobre o perigo do reconhecimento difuso de direitos para as minorias, que na Bolívia poderia ser transferido às maiorias territoriais, em virtude das características demográficas de etnias como a quéchua e a aimarás.

A oposição denunciou, também, que seriam criados governos étnicos autônomos na cidade de El Alto, com quase um milhão de habitantes aimarás. Nas discussões da Constituinte, se escutava ainda que, devido aos novos 
direitos, os camponeses explorariam petróleo para si, entre outros recursos naturais. Entretanto, nada disso se justificava, se examinarmos os artigos propostos pelo MAS. Para que a Constituição fosse aprovada, eram necessários dois terços dos votos, proporção que o MAS não alcançaria sem o apoio do pelo menos parte da oposição. Nesse sentido, o seu projeto foi limitado com o intuito de alcançar os votos necessários. Esta realidade política foi importante na decisão de não desenvolver conceitos; no entanto, isso explica apenas uma parte da abertura, enquanto a outra parte resultou da impossibilidade real de constitucionalizar formas não estatais.

A redação da proposta da Constituição entre aliados resultou também em um campo de conflito, marcado por tensões entre os vários componentes do Pacto de Unidade. A posição "nacional” dos camponeses, por exemplo, limitou a demanda indígena de controlar recursos naturais em seus territórios (VALENCIA; EJIDO, 2010). Apesar das dificuldades para uma tradição classista, "campesinista”, nacionalista ou socialista, aceitar o pluralismo era necessário para manter articulada a base das organizações que apoiavam o governo e tinham constituído a agenda a ser tratada neste momento reforma. A introdução dos elementos propostos pelos indígenas era necessária para que o MAS não perdesse aliados simbolicamente fundamentais na disputa contra a Meia Lua, mas, ao mesmo tempo, mais dificil chegar a um consenso com a oposição. Adiscussão consistiu, então, na forma pela qual estes elementos seriam constitucionalizados, antes de se tratar de sua inclusão ou não. Os indígenas descobriram, assim, que redigir uma constituição consistia em estar alerta às possibilidades da escrita e que constitucionalizar instituições indígenas, muitas vezes, significava não escrever e deixar temas sem definição.

Um exemplo foia autonomia “regional”. Aoposiçãoe parte doMAS contestaram oprojeto de reterritorialização aguardado pelos povos indígenas e organizações, que questionavam uma organização territorial que dividiu etnias e foi resultado histórico da disputa de elites. Mas através da forma "região" - não totalmente explicada, mas introduzida como uma possibilidade na Constituição - as organizações indígenas, como a Assembleia dos Povos Guarani, pretendiam unificar os territórios de suas nações. Por outro lado, a autonomia regional permitiu construir uma autonomia indígena ampla que, em primeira instância, tinha sido reduzida aos municípios existentes cujos limites deviam ser respeitados.

Além das disputas com a oposição, os indígenas de organizações étnicas (terras altas e baixas) deveriam lidar muitas vezes com as posições maioritárias de camponeses ou constituintes urbanos do próprio MAS, que negociava com as suas exigências ou não as entendia, ainda que ao mesmo tempo, as apoiava e incorporava como próprias. A relação era tensa e complexa e a aliança de setores indígenas com outros do MAS, muitas vezes, ficou em suspenso para reaparecer em outros níveis, como entre outros constituintes, ou diretamente com o governo ou, ainda, a margem deste na Assembleia Constituinte. Desta forma, as organizações desenvolveram mecanismos próprios de pressão, lobby, influencia na redação ou recomposição da aliança com os camponeses. O processo foi vivido com muito dramatismo e a velha matriz liberal, com o qual o MAS tinha que negociar, enfrentava principalmente as propostas provenientes das organizações como CONAMAQ (das comunidades das terras altas) e CIDOB (dos povos amazônicos das terras baixas), aliadas às organizações de base do MAS no Pacto de Unidade .

Como exemplo dessa dinâmica, uma proposta do MAS contra as reivindicações indígenas já aceitas pelos 
constituintes deu origem a VI Marcha Indígena das terras baixas em direção à Sucre, que foi suspensa apenas quando suas reivindicações foram reintroduzidas na Assembleia pelo MAS. Essa marcha, que antecipou as que viriam depois da aprovação da Constituição e deu continuidade as que desde 1990 tinham iniciado as demandas por território e pela Assembleia Constituinte, agora exigia a inclusão na Constituição do Pluralismo Jurídico, da Autonomia Indígena sem subordinação, da participação indígena em todos os níveis de governo (através de representação direta e outros mecanismos), dos direitos coletivos e do controle dos recursos naturais renováveis.

Umaimportantereivindicação para os povos indígenas era a participação dos povos minoritários no parlamento. Alguns projetos iniciais estipularam uma representação direta generosa, que substituiria o Senado por uma câmara com representantes de todas as nações indígenas. Era uma das possíveis interpretações do conceito Plurinacional. A oposição rejeitou qualquer tipo de representação étnica ou que não fosse guiada pelo voto individual. Os camponeses do MAS e da Confederação Sindical Única de Trabalhadores Camponeses da Bolívia (CSUTCB) também não viram esta representação das minorias com simpatia. Para o MAS, assim como para o próprio Evo Morales, este partido e os seus parlamentares eleitos por maioria eram os que representariam os indígenas. A resolução constitucional permaneceu aberta, pois dois artigos consecutivos estabeleceram parâmetros contraditórios sobre o tema. Em um deles (artigo 146.VII), determinou-se que "as circunscrições especiais indígenas originárias camponesas serão regidas pelo princípio da densidade populacional em cada departamento". Em outro artigo (artigo 147.III), estabeleceu-se que "a lei determinará as circunscrições especiais indígenas originárias camponesas, onde não deverão ser considerados como critérios condicionais a densidade populacional, nem a continuidade geográfica".

Se este encontro entre comunidade Estado republicano, que tem como protagonista as organizações indígenas, é, por si mesmo, uma das bases da complexidade da nova Constituição, devemos introduzir outro elemento que tornou a Constituição aprovada em 2009 um híbrido de formas liberais e comunitárias e, também, de inspiração social. Na verdade, no novo texto, os termos Social e Unitário vêm junto ao Plurinacional Comunitário na definição do caráter do 
Estado. Junto à visão indígena, muitas propostas do MAS tinham o espírito do Estado de Bem-estar Social e da vontade da soberania econômica. Estas ideias foram mais facilmente traduzidas em artigos e propostas estatais. A Constituição de 1967 teve importantes incorporações do constitucionalismo social, mas na medida em que encontrou resistência por parte dos interesses defendidos pela oposição, era necessário incluí-las de forma fragmentada ou camuflada.

Quando o Congresso boliviano interveio no texto da Constituição em 2008, muitos temas perderam força, foram limitados ou mantidos desde que estivessem cercados de ambiguidade. $O$ limite máximo para a prosperidade da terra de cinco mil hectares, por exemplo, bem como os limites para as concessões de mineração e madeireiras, foram relativizados em disposições transitórias ou de medidas que estabeleceram o caráter não retroativo às mudanças. Tanto Evo Morales como seu vice-presidente Garcia Linera (2011) mostraram a "estratégia" com a qual a Assembleia teria enganado à oposição para introduzir temas sub-repticiamente (como a reeleição e o "controle social" na administração do Estado) ou apresentando propostas mais radicais do que o desejado (como a reeleição indefinida, o Poder social ou congresso Unicameral), para logo chegar a um meio termo que na verdade era o objetivo inicial.

Um exemplo de como os constituintes do MAS articularam distintas posições sem oponentes, incluindo as perspectivas “social" e "étnica", foram as discussões ligadas ao artigo que define o "povo boliviano". Para o liberalismo opositor não era necessária a definição “o povo são os bolivianos e as bolivianas”. A discussão ocorreu principalmente entre constituintes da bancada do MAS e entre as organizações indígenas e camponesas do Pacto de Unidade. Assim, foi possível combinar diferentes perspectivas. A Constituição aberta surgiu especialmente das discussões internas do MAS com constituintes urbanos e rurais, organizações sociais, ONGs, intelectuais e governo escrevendo em conjunto, enquanto driblavam ou incorporavam as ideias da oposição, sempre apresentadas como um impugnação incompatível, mas que eram incorporadas em um novo conjunto heterogêneo. O resultado pode ser pensado em termos do que Lawe Mol identificam como “lista”, por oposição à “ordem”, ou seja, os elementos são unidos sem necessariamente ser parte de um todo maior, sem relações hierárquicas e sem inclusão necessária (LAW; MOL, 2002, p.7).

Em outro trabalho reproduzimos o debate em detalhes (SCHAVELZON, 2010), mas vale a pena mencionar as posturas etnicistas ou classistas que defendiam que o povo fosse definido explicitamente como indígena ou como classe social. A solução aberta foi adicionada sem oposição, inspirada no indianismo katarista dos anos 1970 e 1980 e seu olhar com os "dois olhos" de classe e etnia (ALBO, 1987), e também na ideia de "indígenas camponeses" como um só sujeito político, segundo a proposta do Pacto de Unidade. Essa fórmula central devia permitir a introdução na Constituição de um sujeito coletivo, que foi definido como "nações e povos indígena originário camponeses", aos quais foram acrescentados, no artigo $3^{\circ}$ da Constituição, "as bolivianas e bolivianos", as comunidades "interculturais", - como se autodefiniam os sindicatos de colonizadores, que incluía os cocaleros - y “afro-bolivianas", que passaram a ter direitos iguais aos indígenas em outro artigo da Constituição (REPÚBLICA DA BOLÍVIA, 2009).

Após da revisão no Congresso em 2008, a fórmula teve a última de uma série de modificações. No acordo final, as classes sociais foram excluídas da fórmula e se introduziu o termo "nação". Nos argumentos, os distintos pontos de vista liberais não estavam acostumados a uma definição tão particular do "povo", pela impossibilidade de 
ser decomposta em cidadãos individualizados e por estar associada ao "populismo corporativo" do MAS. A oposição insistia que os mestiços tinham sido excluídos ou discriminados. Para a oposição, faltava algo na definição, mas, ao mesmo tempo, era uma definição redundante e carregada. De acordo com esta última perspectiva, a definição qualificava uma mesma população duas vezes, como "bolivianos" e como "indígenas" (e até mesmo havia quem fosse incluído em três ou quatro subgrupos sobrepostos da definição). Para o ex-presidente entre 2003 e 2005, Carlos Mesa, “a Constituição destrói dramaticamente a premissa básica de que ‘Todos os seres humanos nascemos iguais', ao estabelecer uma categorização da cidadania por origem, cor da pele e idioma, diferenças que levaramà Segunda Guerra Mundial e ao genocídio na África” (LAPRENSA, 2009, s/d). E, em um artigo para a imprensa, em 2012, perguntou: "O imaginário das nações indígenas, suas autonomias e justiça podem ser incorporadas de forma equilibrada, tolerante e razoável à estrutura republicana clássica que ainda permanece no Estado?’'(MESA, 2012, s/d).

As organizações sociais e indígenas ponderaram de forma oposta. Não se tratava apenas de enumerar, senão que reconhecer identidades múltiplas e historicamente exclúdas que deviam ser especificamente nomeadas. As organizações sociais foram claras ao exigir que suas denominações fossem incluídas neste artigo. Para os constituintes do MAS, em vezde redundância, havia complementariedade de definições excludentes: camponeses que eram também indígenas; bolivianas, que eram interculturais. Alguns atores não concordaram, então, que uma vírgula separasse as definições propostas por cada organização do Pacto de Unidade como: indígena, originário e camponesa. Desse modo, no sujeito central da nova Constituição foram incluídas as maiorias (camponeses) e as minorias (indígenas), bem como aqueles que se identificavam apenas como "bolivianos". Nesta definição, as categorias nomeavam diferentes grupos, mas ao mesmo tempo os articulavamem umaúnica definição, mostrando as formas flexíveis, abertas e sobrepostas com as quais muitos bolivianos se autodefinem. Foi o resultado criativo da combinação das visões dos povos minoritários, do pensamento indianista e da perspectiva nacional, socialista e do pluralismo de esquerda.

Por trás dessas inovações constitucionais estava o fato político confirmado no censo de 2001, quando $62 \%$ da população se declarou pertencente a alguma etnia indígena. A identificação indígena generalizada e que não se limitou às comunidades do campo, mas nomeou os quéchua e aymaras da cidade, foi um verdadeiro unificador que - sem eliminar a singularidade - pôde trazer dor de cabeça aos opositores liberais que insistiam em afirmar que alguns daqueles que se autoidentificaram, "na verdade", não eram indígenas; e, acima de tudo, tornou possível a articulação de diferentes elementos que não dilúram sua particularidade nem deixaram de ser também bolivianos, mantendo ou recuperando a sua pertença.

Este reconhecimento étnico generalizado tem muito a ver com a Constituição Aberta. Também como indefinição e ambiguidade, permitiu o "encontro excepcional" de minorias e maiorias camponesas e indígenas, articulando organizações das terras altas e terras baixas, junto a assessores, à esquerda pluralista, a centrais camponeses e a atores do governo do MAS, ou aliados ao MAS, que deram ao processo vários dos seus termos-chave para pensar o país e protagonizaram um encontro que, nem antes nem depois do processo constituinte, se produziria com tanta força.

O resultado do diálogo entre horizontes políticos diferentes levou a que maiorias camponesas do altiplano pensassem para si regimes especiais com o reconhecimento da diferença e autonomia originalmente propostas para 
situações que envolviam grupos étnicos minoritários. Ao mesmo tempo, na conjuntura da Assembleia, minorias indígenas dispersas e isoladas do centro político tiveram a oportunidade de pensar o Estado, pela força das maiorias camponesas que lhes davam apoio numérico para ampliar propostas. Neste encontro constituinte, a temporalidade cíclica dos Andes, onde "o passado fica à frente", "o futuro já foi visto" e onde o presente pode ser uma inversão do espaço-tempo (APAZA APAZA, 2005), articulou-se com a temporalidade linear do discurso do desenvolvimento (ESCOBAR, 1994) e com a espacialidade nômade e antiprodutiva das terras baixas (VIVEIROS CASTRO, 2011).

Este diálogo de singularidades se encontrou, por exemplo, na definição - aberta - do conceito constituinte de Viver Bem. Surgido do contato entre comunidades andinas, política de desenvolvimento e intelectualidade indianista, o conceito de Viver Bem foi traduzido para o Guarani, Yuracaré, bésiro como formas de vida que se comunicavam e adquiriam forma estatal, como alternativa ao desenvolvimento (GUDYNAS, 2011), como políticas públicas, ou, ainda, foi vinculado às formas próprias da comunidade, em oposição ao "Viver Melhor", com que se descreve a lógica da acumulação capitalista (cf. FARAH; VASAPOLLO 2011). Da mesma forma, as discussões a respeito da justiça comunitária obrigavam a questionar os limites de um sistema que estava fechado ao pluralismo, sem definir claramente se daria origem a um novo sistema intercultural, ou a um segmento multicultural da justiça estatal como um tudo. Ficou aberto, assim, se a justiça indígena se estabeleceria como um sistema paralelo em igualdade com o sistema ordinário, se seria introduzida no Estado afetando toda a justiça nacional, ou se ficaria subordinaria ao velho direito estatal.

Na Constituição de 2009, a Bolívia adotou para seu governo a forma democrática, participativa e comunitária (art.11) e o direito das nações e povos indígena originário camponeses exercerem seus sistemas políticos, jurídicos e econômicos de acordo com suas cosmovisões (art. 30.II.14 ); declarou o princípio do pluralismo jurídico (art. 178), que a função judicial é única e que "a jurisdição ordinária e jurisdição indígena originária camponesa gozarão de igual hierarquia” (art. 179). Mas, ao mesmo tempo, estabeleceu que “todo pessoa será protegida oportuna e efetivamente por juízes e tribunais, no exercício dos seus direitos e interesses legítimos" (art. 115) e que "o Estado garante o direito ao devido processo, à defesa e a uma justiça plural", artigos que podem ser interpretados como intervenções dos tribunais "ordinários" na justiça da comunidade, organizada de forma diferente. Em resumo, a definitiva relação entre os dois sistemas não foi resolvido na Constituição. Outro artigo estabeleceu que "a Lei de Deslinde Jurisdicional determinará os mecanismos de coordenação e cooperação entre a jurisdição indígena originária camponesa com a jurisdição ordinária e a jurisdição agroambiental e todas as jurisdições constitucionalmente reconhecidas” (art. 192.III).

Um aspecto importante da abertura e indefinição dos conceitos constitucionais "chaves" consiste em que tais características permitiram manter vigente seu sentido ambíguo, apesar de revisões e cortes impostos pela oposição. Nesse sentido, sua força residiu no que não estava escrito, ainda que dependesse da forma constitucional para se consagrar. De fato, o MAS atendeu a todas as preocupações da oposição, porque sua prioridade era chegar ao referendum e muitos de seus porta-vozes afirmavam, então, que as mudanças continuariam a partir do Governo. Mas, novamente, apesar de "cadeados", controles e "check and balance”, o que pensávamos neutralizado reapareceu, assim como anunciaram as previsões catastróficas que se reacenderam antes de que as mudanças 'imprescindíveis e fundamentais" fossem realizadas. Algo desta força dos silêncios e espaços de ambiguidade de uma Constituição foi percebida por Jorge Lazarte. Em um artigo no jornal La Razón, pouco antes do referendum, afirmou que o perigo da 
“Constituição do MAS “ estava justamente no que não era dito (LAZARTE, 2008). Da mesma forma, no jornal Los Tiempos, de Cochabamba, afirmou que "estamos diante de uma obra mestra da engenharia política mediante a qual, sem dizê-lo explicitamente, se constituiu um quarto poder do Estado", referindo-se ao "Poder Social" que o MAS havia constitucionalizado sem que ninguém se desse conta (LOS TIEMPOS, 2008, grifo do autor).

No âmbito do processo constituinte, os povos indígenas comprovaram duas coisas. De um lado, uma decepção pela impossibilidade de tradução e adaptação do externo na letra do direito estatal. Enquanto o Estado sempre parecia exigir um encerramento de toda discussões jurídica, a comunidade se esforçou para manter abertas as definições como uma possibilidade de existência às margens de um sistema que pretendia controlá-la. Por outro lado, de modo ambíguo, contraditório e aberto, os conceitos políticos como autonomia, comunidade, plurinacionalidade e Viver Bem foram introduzidos, resultando em inovações jurídicas criativas. No trabalho dos redatores, constituintes indígenas, camponeses ou de esquerda tinham transformado suas reivindicações de anos em artigos constitucionais e, assim, já estavam incluídos na política estatal, embora por força da oposição tenham ficado de fora do texto final aprovado. Como um equilíbrio, assim, vemos que é possível unir regimes de práticas políticas diferentes: na Bolívia se deram os passos para fazê-lo.

\section{A CONSTITUIÇÃO ABERTA}

O projeto Plurinacional nasce da vontade constituinte de ir além das políticas multiculturais implementadas na década anterior . Não se tratava de incluir direitos coletivos em um código liberal, como mero reconhecimento de culturas, de acordo com a crítica das comunidades originárias e povos indígenas que abriram o processo constitucional. Em vez disso, tratava-se de transferir o poder político e territorial para os processos de poder local e de autonomia. $\mathrm{O}$ Estado Plurinacional buscou ao mesmo tempo cumprir uma agenda de soberania econômica dos recursos naturais, terra, direitos básicos e combate à desigualdade com “desenvolvimento", controle estatal da economia e das políticas sociais. Eram diferentes visões que, apenas depois da aprovação da Constituição, tomaram caminhos diferentes e até mesmo opostos.

Observadores internacionais chamaram a atenção para a importância da proposta constitucional. Boaventura de Sousa Santos identificou a possibilidade de um constitucionalismo "experimental" e "pós-colonial" que permitiria superar a crise irreversível da democracia liberal do Estado moderno com uma "demodiversidade" que possibilitava a combinação de vários tipos de democracia. Dirigindo-se aos constituintes, o sociólogo Português recomendou deixar algumas questões “abertas”, para que as soluções que ainda não estavam presentes pudessem ser encontradas no futuro. Assim, "o povo manteria o poder constituinte em suas mãos e sua força não seria absorvida pela poder constituído" (SOUSA SANTOS, 2008, p.22). Bartolomé Clavero, da Universidade de Sevilla, definiu a Constituição da Bolívia como "primeira Constituição realmente emancipadora em todas as Américas" (CLAVERO, 2008, p.80) e "a primeira que rompe de modo decidido com o trato tipicamente americano do colonialismo ou constitucionalismo colonial desde a época da independência" (p.79). Em outro trabalho, Clavero propôs pensar em um "Estado de Direito" a partir dos direitos dos povos indígenas americanos, como uma crítica ao "Estado Direito", no singular, uma vez que a invenção 
europeia não permite se livrar da "hipoteca colonial”" (2006, p.684).

O filósofo e doutor em direito Farit Rojas Tudela definiu este constitucionalismo como um giro desconstrutivo do "pluralismo jurídico pós-colonial" que vai além da concepção liberal dos direitos fundamentais, com a proposta de um “Direito maleável e de direitos com qualidades porosas" que superam o monismo jurídico de gradação hierárquica e a própria concepção de Estado-nação. Ao contrário de Clavero, Rojas Tudela prefere falar de um Direito singular, na condição que seja plural e poroso. Em sua definição de pluralismo jurídico, os ordenamentos jurídicos "não são concebidos como entidades separadas e independentes, mas convivem em interseção, mistura e interação". Esta é uma "constante construção de interlegalidade de ordens jurídicas porosas", escreve Rojas Tudela, e "não são nem totalmente abertas, nem totalmente fechadas. Não se fala de muitos direitos ou de muitos ordenamentos jurídicos, mas de um só Direito e ordem jurídica plural, aberta e em constante construção" (ROJAS TUDELA, 2012, s / d).

Sobre a Constituição de 2009, o autor considera que os direitos, deveres e garantias conservam, em parte, a natureza individual da tradição ocidental do constitucionalismo liberal, "mas, também, apresentam a possibilidade desconstrutiva crítica através de figuras como o pluralismo jurídico e os direitos das nações e povos indígenas originário campesinos". Rojas Tudela cita o artigo 178 da Constituição em que se abrem as portas para a pluralidade de fontes do direito, ao estabelecer que “o poder de exercer justiça emana do povo boliviano". Ele traz o exemplo da "cláusula numerus apertus" (ou cláusula número aberto de direitos), que se refere a direitos “de devenir, de por vir", derivados de outras matrizes civilizatórias e presentes nessa Constituição. São também nesse sentido, segundo ele, os artigos 1,9,30, 98 e 179 da Constituição (ROJAS TUDELA, 2012: s / d).

Em janeiro de 2009, Raúl Prada apresentou a sua leitura da Constituição em um discurso em La Paz (SCHAVELZON, 2010). Ele via duas linhas que determinavam o texto e o processo. A matriz do texto são os movimentos, daí o seu estado original e originário, disse ele. Mas havia também o caráter formal, que se manifestava na intervenção do Congresso em vários momentos do processo (lei de convocação, de ampliação, modificação final), que conferiu ao ato constituinte um caráter constituído. Eram estas duas racionalidades, a do constituinte e a do constituído, que explicavam para este autor a tensão presente desde o primeiro artigo da Constituição. Prada observou algumas tensões centrais no novo texto constitucional, em cujo processo de transição se encontraram a tutela e a autonomia indígena; o plurinacional comunitário e o direito social; a industrialização capitalista e o Viver Bem.

Em um texto posterior, Prada nos permite adicionar um elemento à análise. Apesar da revisão do Congresso, escreve o ex-constituinte do MAS, a Constituição conserva seu “espírito": "o Congresso, declarado constitucional, fará 144 modificações, revisando cento e vinte artigos, no entanto, não poderá mudar o espírito constituinte e a vontade constituinte, expressa na própria estrutura da Constituição, na visão do país e no modelo de Estado". (PRADA, 2010). Esta análise é interessante porque vai na mesma direção das nossas observações de campo, quando, apesar das modificações, a oposição insistia com suas críticas "para além do texto", de alguma forma talvez em direção a seus silêncios constitucionais.

Contrário a um constitucionalismo do "não dito", um dos debates que surgiram logo depois de aprovada a Constituição atacava as frequentes referências à Pachamama no discurso político do governo (esta citação foi 
mencionada no preâmbulo da Constituição). Era uma discussão na fase pós-constituinte que dava continuidade direta às disputas da Assembleia. A crítica à Pachamama e aos elementos indígenas-comunitários do processo afirmava que os componentes não modernos eram "apenas" retóricos, sem materialidade ou status de realidade dos componentes modernos como o Estado republicano ou economia liberal de mercado. Esta posição era geralmente acompanhada pelo questionamento do caráter indígena dos camponeses quéchuas e aimarás urbanos ou migrantes. Mas havia uma assimetria básica nesta forma de pensar supostamente ocidental (e portadora de valores universais) ao separar economia e cultura, colocando o indígena no segundo termo e ignorando a importância dos distintos pensamentos que "recortam" o mundo de modo diferente. Essa perspectiva não compreendia conceitos como o Viver Bem e reciprocidade, irredutível a apenas uma cultura ou uma economia, tão "simbólicos" e "práticos" como a economia liberal, ficção política a que estes críticos não exigem a mesma "realidade" ou coerência que as práticas comunitárias. Liberalismo e Comunitarismo na Bolívia, no entanto, não são suficientes por si só para explicar "a realidade" econômica ou política.

O antropólogo colombiano Arturo Escobar (2010) interviu no debate boliviano para apresentar o problema em termos de duas posições de sujeito: intelectuais-políticos "pachamámicos" e "modérnicos". São duas "vozes sociais" que falam da 'configuração de conhecimento ou 'episteme' na qual elas têm origem e da ontologia ou das premissas básicas sobre o mundo que levam". Este autor se referia às críticas da oposição ao MAS e do jornalismo que se dirigiam aos elementos indígenas do discurso do governo e da proposta constitucional aprovada, entre outros a do jornalista e pesquisador Pablo Stefanoni (cf.2010, a, b e c). Para Escobar, esta posição, que reduz a cosmopolítica indígena a "mera retórica", se inscreve no contexto do pensamento moderno "eurocêntrico" como desqualificação do conhecimento considerado "não-científico", "local", "romântico", "incompleto". Escobar insere essa discussão boliviana na crise do modelo euro-modernidade, definida por uma ontologia e modelo de mundo dualista (que separa sujeito e objeto, natureza e cultura, indivíduo e comunidade). Arturo Escobar menciona alguns movimentos sociais e tendências nãodualistas que anunciam "o surgimento da relacionalidade como fato epistêmico, social, político e cultural de grande importância no milênio", "algo assim como 'a revanche da relacionalidade"”.

Referindo-seaoselementos indianistas daConstituição, Stefanoniconsiderouque, casoestessedesenvolvessem, poderiam levar a uma teocracia culturalista. No entanto, em sua opinião, esta é uma ameaça não realizada que reduz os elementos "pachamâmicos" a :

“(...) um discurso difuso e vazio (de alguns, não todos, decoloniais, subalternistas e autonomistas, além de adeptos a outras correntes pós-modernas) sobre a Pachamama e uma suposta epistemologia antimoderna, que constrói uma cosmovisão andina de salão e age como ventríloquos dos indígenas realmente existentes, de quem se atribui sua representação". (STEFANONI, 2010b, grifo do autor)

Esta definição parece a chave, se pensarmos nas características abertas, difusas e ambíguas do novo texto constitucional. Stefanoni fala de um discurso "difuso e vazio", que longe de significar rastros de uma cosmopolítica diferente na Constituição Aberta, no mesmo sentido da oposição liberal já citada, se reduz à "cosmovisão andina de salão", em suas palavras. 
acima nesta seção - , a abertura deve ser destacada como uma forma que permite a presença da comunidade no Estado. A indefinição e os silêncios ("o vazio"), longe de ser visto como um discurso populista ou mentiroso, em vários casos, podem ser entendidos como uma forma de proteger as reivindicações indígenas e os movimentos sociais frente a um contexto político adverso. Falam-nos, também, sobre a presença de uma ontologia diferente que do ponto de vista da política republicana é uma fonte constante de equívoco, desentendimentos e reducionismo (cf. BLASER 2009; VIVEIROS DECASTRO, 2004). No lugar de carência ou debilidade dos constituintes, assim, a falta de definição pode ser interpretada como a forma pela qual as instituições da oralidade e as formas sociais alternativas foram introduzidas no Estado, sem ser totalmente distorcidas.

\section{CONCLUSÃO: A CONSTITUIÇÃO ABERTA E O ESTADO PLURINACIONAL}

Na tentativa de ir além da tendência que incorpora ao liberalismo republicano os direitos culturais coletivos culturais (cf. TAYLOR, 1993; KIMLICKA, 1996) e os direitos sociais (cf. MARSHALL, 1950), a proposta do MAS, inspirada no Pacto de Unidade, gerou fragmentos de um constitucionalismo diferente delineado no novo texto, ainda quenãodesenvolvido. Coma proposta plurinacional, pela primeiravezos direitos indígenas nãoseriamobjeto deapenas de alguns artigos ou, no máximo, de um capítulo constitucional, como em várias constituições latino-americanas. Com o fundamento do caráter maioritário da população autorreconhecida como indígena, os povos originários tiveram de fato presença na Assembleia e deixaram sua marca na Constituição.

De forma inesperada, a Constituição Aberta propôs um Estado pós-republicano-liberal como a Constituição possível de "camponeses indígenas" e aliados, introduzindo mudanças decorrentes do encontro de subjetividades diversas em aliança política e, especialmente, abrindo caminhos a ser percorridos fora do cenário institucional da Assembleia Constituinte. Esta foi também uma Constituição impossível, que constitucionalizou temas sem que adversários percebessem ou pudessem neutralizá-los com revisões. Os silêncios floresceram em territórios ou novas práticas com um significado que se revelaria mais tarde, mas que já estava presente como possibilidade.

De alguma forma, tratava-se de uma disputa sobre fantasmas que poderiam mobilizar símbolos cruciais com significados para os bolivianos, mas que também poderiam desaparecer como retórica que não se referia a nada concreto ou como práticas clandestinas invisíveis para o Estado e seus aparatos de enunciação. A força desse novo constitucionalismo, como reflexo da força indígena na Bolívia, pode ser visto na virulência com que reagiu a oposição, mobilizada na Meia Lua e em Sucre, embora os perigos advertidos por ela não tivesse expressão real no texto da Constituição e suas demandas terem sido incorporadas. De dentro das instituições, ou em suas lacunas e fissuras, surgiu uma crítica à matriz liberal que, com a chegada de camponeses e indígenas, questionava a ordem constitucional estabelecida.

De forma sub-reptícia ou difusa, a proposta do MAS buscou ir mais longe em questões estratégicas para o liberalismo e a república. Sem dizer claramente, mas insinuando, o Estado buscou a partir de dentro a sua própria descolonização. A forma república, defendida pelos liberais contra os "indígenas camponeses", foi questionada por diferentes maneiras de compreender a propriedade (com a territorialidade coletiva e reconhecimento da ancestralidade), a forma representativa de governo (com a inclusão da representação direta dos povos no parlamento), o sistema jurídico 
do direito positivo (com a jurisdição indígena camponesa) e a divisão de poderes (com o controle social).

Como mencionamos, no entanto, antes de uma nova ordem constitucional, essas discussões nos permitem compreender um projeto político que introduz a visão indígena e também um liberalismo, um socialismo e um nacionalismo local. O liberalismo era "regionalista" porque a partir da perspectiva universalista não evitou que se tratasse de expressões relacionadas com demandas como a autonomia departamental da Meia Lua e a transferência da capital para Sucre. A invisibilidade dos híbridos ou misturas se associava a um "institucionalismo" que não reconhecia a realidade do que está fora, ao que irrompe e ao inesperado dentro do sistema político vigente; também, agregava-se à universalidade de um liberalismo que falou de "República" e "Estado de Direito", com sentidos tão locais como "descolonização", "viver bem" e "plurinacionalidade", que na Assembleia estavam relacionados às demandas indígenas, mas também sociais, de esquerda e até nacionalistas, em defesa da soberania econômica.

Enquanto alguns traduziam e reduziam Viver Bem a "desenvolvimento sustentável”, Plurinacionalidade e Descolonização a "Multiculturalismo" e "Bem-Estar", apelando a um princípio que permitia a comparação com sistemas de políticas tomadas como modelo, a versão autóctone foi a que mais prevaleceu como expressão da voz indígena em um novo constitucionalismo distinto das posições liberais, que se revestiram de validade universal e foram justificadas a partir de um sentido prático do vigente nas instituições estatais.

Essas formas políticas justapostas e combinadas eram acessíveis apenas a partir de um olhar também aberto à complexidade. Aimarás liberais, socialistas indianistas, mestiços pachamâmicos e republicanos comunitaristas, ao lado de formas selvagens, comunitárias ou em busca de soberania e inclusão social foram incluídos na Constituição Aberta, indefinida, com silêncios estratégicos e negociações forçadas que resultaram na coexistência de vozes e perspectivas cosmopolíticas distintas. Da mesma forma, foi possível observar como na proposta de "indianismo social", muitas vezes a nação não era contraditória com a plurinação, e que também era possível falar ao mesmo tempo de Estado e contra-Estado, ou de um projeto de estatal que buscava autonomia para os povos, mas também procurava fortalecer um Estado que interviria na economia para garantir o bem-estar.

Pouco depois de aprovada a Constituição, em 2009, duas posições articuladas em tensão durante a Assembleia e no Pacto de Unidade se desdobraram e distanciaram em um processo no qual as organizações "indígena originário campesinas" se tornaram organizações indígenas e sindicatos campesinos separados. A defesa da comunidade, do território autônomo e do Viver Bem, a partir de uma posição das minorias, se afastou cada vez mais da defesa inclusiva do Estado em um projeto desenvolvimentista, produtivo e industrial para as maiorias e com apoio camponês. Este distanciamento apenas destaca a complexidade e a excepcionalidade do momento constituinte, onde maiorias e minorias em diálogo criaram conceitos políticos e mediram a possibilidade de pensar a descolonização e a sociedade indígena no Estado. 


\section{BIBLIOGRAFIA}

ALBÓ, Xavier. From MNRistas to Kataristas to Katari. In: STEVE, J. Stern (ed.). Resistance, Rebellion, and Consciousness in the Andean Peasant World: 18th to 20th Centuries. Madison: University of Wisconsin Press, 1987, p.379-419.

APAZAAPAZA, I. Concepción y estructura de metáforas temporales en la lengua aymara. Palestra na XIX Reunião Anual de Etnología do Museo Nacional de Etnografia y Folklore, realizada de 24 a 27 de agosto de 2005 em La Paz, 2005.

BARRAGÁN, R. Asambleas Constituyentes. Ciudadanía y elecciones, convenciones y debates (1825-1971). La Paz: Muela del Diablo, 2006.

CHAKRABARTY, Dipesh Provincializing Europe: Postcolonial Thought and Historical Difference; Princeton: Princeton University Press, 2007.

CLAVERO, Bartolomé. 2006: Estado de Direito, direitos coletivos e presença indígena na América In: COSTA \& ZOLO (orgs.). O Estado de Direito. História, teoria e crítica, São Paulo: Martins Fontes. 2006, p. 649-685

Geografia Jurídica de América Latina. Pueblos Indígenas entre Constituciones Mestizas. México DF: Siglo XXI, 2008.

COLBURN, F. \& A. CRUZ. Varieties of Liberalism in Central America. Nation-States as Works in Progress. Austin: University of Texas Press, 2007.

CORSIN JIMÉNEZ, Alberto. An anthropological trompe l'oeil for a common world. An essay on the economy of knowledge. Oxford: Berghahn Books, 2013.

DE SOUSA SANTOS, B. Pensar el Estado y la Sociedad: Desafíos Actuales. Conferencias de Boaventura de Sousa Santos. La Paz: CLACSO, Muela del Diablo, Comuna, CIDES-UMSA, 2008.

DE LA CADENA, M. Indigenous Cosmopolitics in the Andes: Conceptual Reflextions beyond 'Politics'. Cultural Anthropology 25(2): 334-370, 2010.

DELEUZE, G. y F. GUATTARI. Mil mesetas. Capitalismo y Esquizofrenia. Valencia: Pre-textos, 2000.

- TESCOBAR, A. ¿"Pachamámicos" versus "Modérnicos"? Comentario breve a los textos de Pablo Stefanoni sobre el ,pachamamismo “e”. Publicado en Política y Economía, de CLAES/D3E, 25 de maio de 2010. Disponível em: http://www.politicayeconomia.com/2010/05/\%c2\%bfpachamamicos-versus-modernicos/ (consultado 19 de mayo 2012)

. Encountering Development: The Making and Unmaking of the Third World. Princeton: Princeton 
GARCÍA LINERA,A. El "oenegismo", enfermedad infantil del derechismo (O cómo la "reconducción" del Proceso de Cambio es la restauración neoliberal). Vicepresidencia del Estado Plurinacional, Presidencia de la Asamblea Legislativa Plurinacional, La Paz, 2011. Disponível em: http://www.vicepresidencia.gob.bo/Portals/0/documentos/ EL-OENEGISMO.pdf (consultado 19 de mayo 2012).

GUDYNAS, E. Buen Vivir: Germinando alternativas al desarrollo". Amé-rica Latina en Movimiento, no. 462: 1-20, ALAI, Quito, 2011.

HALE, CH. El liberalism mexicano en la época de Mora. México D.F: Siglo XXI, 1972.

KIMLICKA, Will.Ciudadanía multicultural. Barcelona: Paidós, 1996.

KLEIN, Herbert, 2011: AConcise History of Bolivia. Cambridge: Cambridge University: 2011.

LA PRENSA 1o. de Agosto 2009. Controversia De la República al Estado Plurinacional. Revista Domingo: 1 de Agosto: s/d, La Paz. Disponível em:. http://eju.tv/2009/08/controversia-de-la-repuacute-blica-al-estado-plurinacional/ (consultado 19 de mayo 2012).

LATOUR, B. Jamais Fomos Modernos. Ensaio de Antropologia Simétrica. Coleção TRANS. Rio de Janeiro, v. 34, 1994.

LAW, J. and A. MOL (Eds.). Complexities in Science, Technology and Medicine. Durham/EUA: Duke University, 2002.

LAZARTE, J. La Asamblea Constituyente de Bolivia. El pacto era necesario, ¿por qué no fue posible? In: ZUAZO O., M. y QUIROGA SAN MARTÍN, C. (coord.) Lo que unos no quieren recordar es lo que otros no pueden olvidar. Asamblea Constituyente, descolonización e interculturalidad. La Paz: FES-ILDIS, 2011, p.319-431.

. Etnocracia y democracia. La Razón. La Paz, 3 de dezembro de 2008.

LOS TIEMPOS. La esencia del proyecto del MAS, Cochabamba, 31 de outubro de 2008.

MARSHALL, T.H. Citizenship and social class and other essays. Cambridge: CUP, 1950.

MESAGISBERT,CARLOS.2012. Tres grandes aplazos. Columna vertebral CarlosD. Mesa Gisbert, periódico Página Siete, Mayo 26, La Paz. Disponível em: http://www.paginasiete.bo/2012-05-27/Opinion/Destacados/18Opi00127-0512-P720120527DOM.aspx (consultado 19 de mayo 2012).

MOLINA, F. La Ideología de la Constitución. La Paz: CIPE, Fundación Milenio, 2009.

. El puré ideológico del Gobierno. Página Siete, Agosto 7, La Paz, 2011. Disponível em: http://www. paginasiete.bo/2011-08-12/Opinion/Destacados/17Opi00112-08-11-P720110812VIE.aspx (consultado 19 de mayo 
MORIN, E. L'intelligence de la complexité. L'Harmattan: París, 1999.

PRADA ALCOREZA, Raúl. Crisis y Cambio. Umbrales y horizontes de la descolonización. Ensayo histórico y político sobre la relación de la crisis y el cambio, 2010. Inédito. http://xa.yimg.com/kq/groups/21310050/537852541/.../ Crisis+y+Cambio.doc (consultado 19 de mayo 2012).

POVINELLI, Elizabeth A. The Cunning of Recognition: Indigenous Alterities and the Making of Australian Multiculturalism. Durham: Duke University, 2002.

REPÚBLICA DE BOLIVIA. 2009: Constitución Política del Estado. http://pdba.georgetown.edu/Constitutions/ Bolivia/bolivia09.html (consultado 19 maio 2012).

RIVERA CUSICANQUI, Silvia. Chhixinakax utxiwa. Una reflexión sobre prácticas y discursos descolonizadores. In: Mario Yupi (comp.) Modernidad y pensamiento descolonizador. Memoria del Seminario Internacional. La Paz: U-PIEB IFEA, 2006, p.3-16.

ROJAS TUDELA, F. Constitucionalismo Plural. s/d. Artigo inédito, 2012.

SCHAVELZON, Salvador.AAssembleia Constituinte daBolívia:EtnografiadeumEstadoPlurinacional, 2010. Tese de doutorado, defendida 25/10/10, PPGAS/Museu Nacional/UFRJ, Brasil. Disponível em: http:/www.dominiopublico. gov.br/pesquisa/DetalheObraForm.do?select_action=\&co_obra=199561 (consultado 19 de maio 2012).

SERHAM Jaldin, Gamal. La Historia no oficial de la Asamblea Constituyente. Revista Opiniones y Análisis. La Paz: Hanns Seidel Stiftung ev, FUNDEMOS, 2008.

STENGERS, I. Cosmopolitics II. Minneapolis: University of Minnesota, 2011.

STEFANONI, P. ¿Adónde nos lleva el pachamamismo? Rebelión. Disponível em: http://www.rebelion.org/noticia. php?id=104803, 2010a.

- Pachamamismo ventrílocuo [sic]. Disponível em: http:/www.amigo-latino de/indigena/noticias/ newsletter_5/341_pachamamismo_ps.html, 2010b.

. Indianismo y pachamamismo. Periódico Página 7, La Paz. Disponível em: http://www.rebelion.org/noticia. php?id=105233, 2010c.

TAYLOR, Charles. El multiculturalismo y la política de reconocimiento. México: Fondo de Cultura Económica, 1993.

URENDA, J.C. El Estado Catoblepas. Un Estudio Didáctico sobre la Constitución. Las contradicciones destructivas del Estado Boliviano. Santa Cruz de la Sierra: Edición bilingüe 2009.

VALENCIA, M. del Pilar, ÉGIDO, Iván. Los Pueblos Indígenas de Tierras Bajas en el Proceso Constituyente Boliviano. Santa Cruz de la Sierra: CEJIS, 2010. 
VIVEIROS DE CASTRO, E. Posfacio. O intempestivo, ainda. In CLASTRES, Pierre. Arqueología da Violencia. São Paulo: Cosaq\&Naify, p. 297-361, 2011.

- Perspectival anthropology and the method of controlled equivocation. Tipití Journal of the Society for the Anthropology of Lowland South America, v.2, n.3, p.3-22, 2004.

WAGNER, Roy The Invention of Culture. Chicago: University of Chicago, 1975.

ZUAZO O., M. y QUIROGA SAN MARTÍN, C. (coord.) Lo que unos no quieren recordar es lo que otros no pueden olvidar. Asamblea Constituyente, descolonización e interculturalidad. La Paz: FES-ILDIS, 2011. Disponível em: http:// library.fes.de/pdf-files/bueros/bolivien/08870.pdf(consultado 19 de mayo 2012).

\section{NOTAS}

i. Na nova Constituição, os direitos indígenas são encontrados nos artigos: 2, sobre sua preexistência, autodeterminação, autonomia, autogoverno e território; 3 , sobre o seu lugar na nação e no povo; 4 , sobre o respeito a suas crenças espirituais; 5 , sobre a oficialização de idiomas; 8 , valores; 11 , sobre a forma comum de governo; 24, sobre a eleição direta; 30 e 31, com a enumeração de vários direitos, entre eles a autodeterminação, territorialidade e instituições próprias; 35 e 42, sobre a medicina tradicional; 80, 83, 86,91 e 93, sobre a educação; 98 e 100, sobre o património e conhecimento; 146 e 147, sobre a participação no parlamento; 179, 190 a 192 , 197, 199 e 206, sobre justiça e participação em tribunais; 209 a 211 sobre representação política; 265, sobre integração com povos indígenas do mundo; 278, sobre representantes legislativo dos departamentos; 284, sobre representações especiaisemmunicípios;289a296e304, daautonomiaindígena;307, sobreorganizaçãoeconômicacomunitária;337 sobreturismocomunitário;352 e 353, sobre a consulta prévia por recursos naturais e participação de benefícios; 388, sobre aproveitamento florestal; 392 sobre produtos extrativistas tradicionais;394,dapropriedadecoletivaecomunitária;395,sobredotaçãodeterras;403, sobreoterritórioindígenacampesino, direitoaaproveitamento exclusivo de recursos naturais renováveis, consulta e participação nos benefícios, entre outros itens (ver REPÚBLICA DA BOLÍVIA, 2009).

ii. O caráter "pluriétnico e multicultural" da Bolívia foi incorporado à Constituição de 1994, em uma das reformas à Constituição de 1967. Junto com esta declaração, o governo realizou a implementação de políticas interculturais de educação, políticas de reconhecimento territorial e de participação política, com a atuação do vice-presidente aymara e autodefinido como liberal, Víctor Hugo Cárdenas. Após dez anos dessas reformas, as organizações indígenas e camponesas haviam aumentado seu protagonismo e, também, elaborado uma densa agenda política e técnica, com críticas e propostas que foram consideradas na Assembleia Constituinte. 